\title{
GEOCHEMICAL AND MINERALOGICAL CHARACTERISTICS OF LITHOMARGIC CLAY TYPES FROM AWASO BAUXITE DEPOSIT, GHANA: IMPLICATIONS FOR POSSIBLE INDUSTRIAL UTILIZATION
}

\author{
F.W.Y. Momade ${ }^{1}$ and S.K.Y Gawu ${ }^{2}$ \\ ${ }^{1}$ Department of Materials Engineering, \\ Kwame Nkrumah University of Science and Technology, Kumasi, Ghana \\ ${ }^{2}$ Department of Geological Engineering, \\ Kwame Nkrumah University of Science and Technology, Kumasi, Ghana
}

\begin{abstract}
Geochemical and mineralogical methods were employed in characterizing lithomargic clay types underlying Awaso lateritic bauxite deposit in southwestern Ghana in order to assess their suitability for possible industrial utilization. Representative samples analyzed from the deposit revealed kaolinite and gibbsite as the dominant minerals whilst accessory minerals found included goethite, rutile, biotite and muscovite with quartz conspicuously absent. It is possible to wash and separate most of the gibbsite component, which is prevalent in the $>90 \mu \mathrm{m}$ size fractions. On the basis of the results obtained from chemical and mineralogical analyses as well as diagnostic evaluative analyses, the lithomargic clay types could be exploited in the production of aluminium sulphate (alum) for water purification and alumino-silicate refractory material. The raw clay will however have to be beneficiated in order to optimize grade and recovery.
\end{abstract}

Keywords: Lithomarge; Kaolinite; Alum; Mineralogy; Geochemistry

\section{INTRODUCTION}

Two major processes have been reported to be responsible for the formation of most lateritic bauxite deposits in the tropical and subtropical regions of the world (Hurblut and Sharp, 1998). The first process involves a direct transformation of alumino-silicate source rocks through interplay of physical, chemical and biological weathering processes resulting in a residual deposit rich in aluminium. The second is an indirect process characterized by the weathering of source rocks through a clay-mineral stage, followed by, a transformation to bauxite by a further removal of alkali, alkaline earths and silica. In the process, the silica of the feldspars is carried away and the hydrous alumin- ium oxides are left behind. The weathering process can be simplified by the following reaction (equation 1):

$\mathrm{K}_{2} \mathrm{O} \cdot \mathrm{Al}_{2} \mathrm{O}_{3} \cdot 6 \mathrm{SiO}_{2}+\mathrm{H}_{2} \mathrm{O}+\mathrm{CO}_{2}$

$=2 \mathrm{Al}(\mathrm{OH})_{3}+6 \mathrm{SiO}_{2}+\mathrm{K}_{2} \mathrm{CO}_{3}$

When the weathering process is via claymineral formation, there is an accumulation of lithomargic clay below the bauxite layer, separating it from the underlying source rock. Equation 2 typifies the reaction.

$\mathrm{K}_{2} \mathrm{O} \cdot \mathrm{Al}_{2} \mathrm{O}_{3} \cdot 6 \mathrm{SiO}_{2}+2 \mathrm{H}_{2} \mathrm{O}+\mathrm{CO} 2$

$=\mathrm{Al}_{2}\left(\mathrm{Si}_{2} \mathrm{O}_{5}\right)(\mathrm{OH})_{4}+4 \mathrm{SiO}_{2}+\mathrm{K}_{2} \mathrm{CO}_{3}$ 
All the major Ghanaian bauxite deposits (Figure1), four in number, are underlain by such variegated clays through indirect bauxitization processes (Kesse, 1985).

The petrological, geochemical and genetic relations characterizing the bauxite working mine at Awaso were previously examined (Gawu, 1993). The geochemical and textural trends showed that the lateritic bauxite profile could be divided into three distinct zones, namely, the upper bauxite, the middle bauxite and lower clay zones (Gawu, 1997). The production of alum from Awaso bauxite has been previously investigated (Acquah et. al, 1999). Of current interest is the lower clay zone which is the transition zone between bauxite and unaltered parent rock. It is made up of variegated soft silty clays in shades of brown, white and orange yellow with the presence of relic textures from the bedrock. The presence of relict textures provides evidence of its residual nature. The thickness of this zone may well be over eight meters and there is probably a high tonnage of lithomargic clay underlying the bauxite although the actual estimated quantity has not been established.

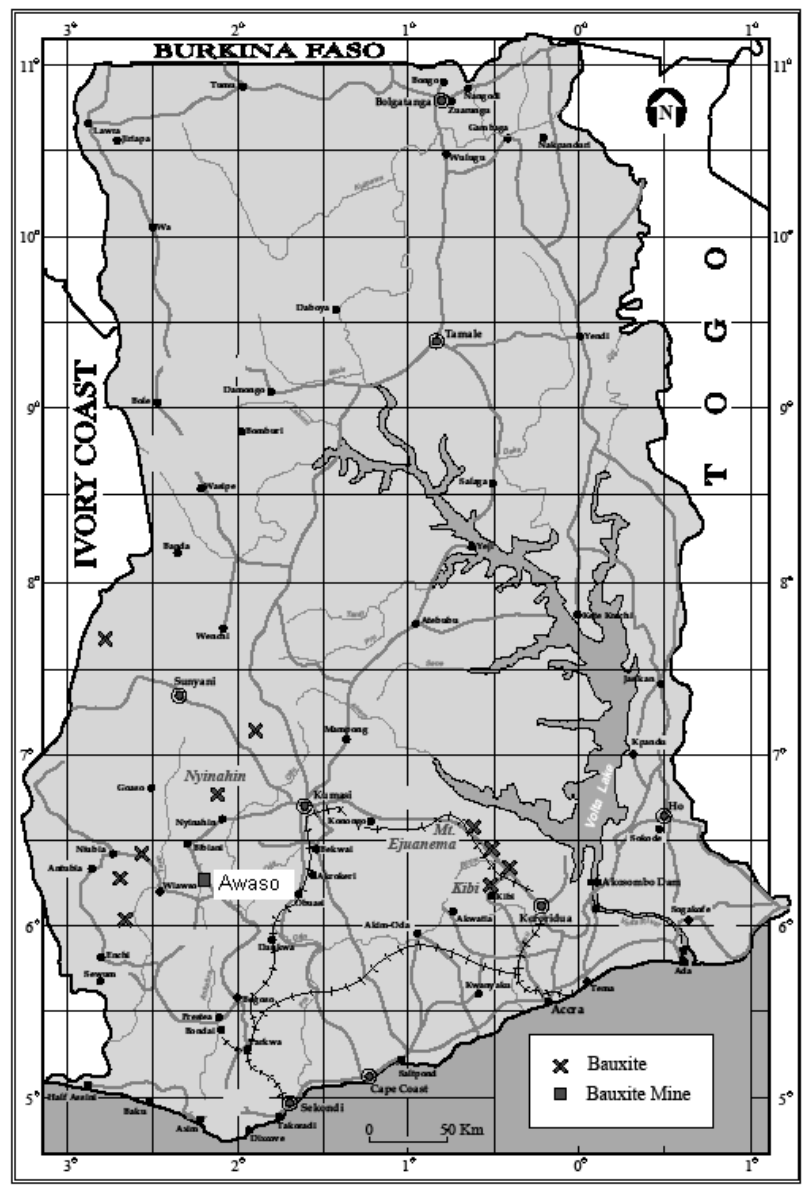

Fig. 1: Ghanaian bauxite deposits and Awaso bauxite mine location (courtesy Minerals Commission, Ghana) 
This clay is normally regarded as gangue (waste) during mining. As the literature indicates, the products of the weathering process include minerals, which could be used as an industrial raw material if proven to be of the desired quality and quantity. Clay studies are regularly mentioned in the literature but there are very few studies, albeit not very recent, on the possible industrial utilization of lithomargic clays, for example, the strength behaviour of such clays with varying moisture contents has been investigated for road construction projects (Shankar and Suresha, 2006).

Clays in general are used for a variety of purposes. These include their use as raw material for the ceramics, refractory and cement industries, as filling material in the pulp and paper, toothpaste and paint industries as well as for production of aluminium sulphate (alum), among others. The particular application depends on the physical, chemical and mineralogical characteristics of the clay. A survey conducted by Appiagyei (1993) and updated by Gawu and Momade (1998) on the use of clay and clay products in Ghana, revealed that a number of industries concerned with the manufacturing of paints, rubber and plastics have been using clay as filling material. Metallurgical industries have also been importing refractory materials, which can be produced from clay, for lining furnaces. The water industry also uses aluminum sulphate for purification cases.

This paper reports on the investigations carried out for the purpose of characterizing the lithomargic clays from the Awaso bauxite mine. The physical characteristics, as well as the chemical and mineralogical composition of representative samples from the appropriate horizons were determined and their implication for industrial use was proposed and partially investigated.

\section{SAMPLING}

The sampling procedure adopted provided for the lateral as well as the vertical variations in the physical properties of the clay. Samples were collected from the transition zone between the bauxite and the unaltered parent rock.

Two sets of samples were collected for analysis. The first set, numbering five (A1 - A5), were taken from the northwestern section of the mine, where the lithomarge was well exposed after a bulldozer had carefully ripped the bauxite off leaving the clay. Based on the physical properties, these samples appear to give a fair representation of the clay types present and hence believed to give a good lateral coverage of the clay types.

The second set of four samples (BW1 - BW4), were collected from the southwestern portion of the mine where bauxite mining reached level three and exposed the lithomarge. An excavator was used to fully expose the clay at four locations to a depth of about three metres each. About $50 \mathrm{~kg}$ samples were collected from each pit, having noted that there was some uniformity in each pit. There was further sub sampling to obtain representative samples for laboratory analysis.

\section{PHYSICAL CHARACTERISTICS OF THE LITHOMARGIC CLAY \\ Colour and Texture}

The samples were noted to be variegated soft silty clays in shades varying from white through light pink, light brown to reddish brown depending on the kaolinite, gibbsite or hydrous iron oxide content. The discrete gibbsite crystals were pinkish in colour. The texture was greasy if no gibbsite crystals were present or gritty if it contains some gibbsite crystals.

\section{Particle Size Distribution}

A 200-g portion of a sample (BW4) was washed through a series of sieves. The mass retained on the various sieves are tabulated in Table 1. The data indicated that as much as $62 \%$ by mass of the sample was under $90 \mu \mathrm{m}$. The fractions above $90 \mu \mathrm{m}$ were pinkish in colour. Similar results were obtained with the other samples.

An interesting observation especially with samples BW3 and BW4 was that discrete particles

98 Journal of Science and Technology, Vol. 29, No. 2, Aug., 2009 
Table 1: Results of wet particle size analysis of sample BW4

\begin{tabular}{cccc}
\hline $\begin{array}{c}\text { Sieve aperture } \\
(\boldsymbol{\mu m})\end{array}$ & $\begin{array}{c}\text { Material retained } \\
(\boldsymbol{\%})\end{array}$ & $\begin{array}{c}\text { Sieve aperture } \\
(\boldsymbol{\mu} \mathbf{m})\end{array}$ & $\begin{array}{c}\text { Material retained } \\
(\boldsymbol{\%})\end{array}$ \\
\hline 4000 & 10.3 & 250 & 10.7 \\
2000 & 1.9 & 125 & 7.4 \\
1000 & 1.8 & 90 & 0.8 \\
500 & 4.8 & Under 90 & 62.3 \\
\hline
\end{tabular}

of probably gibbsite could be separated by sieving. These results are very significant in determining the possibility of separating the gibbsitic fraction from the kaolinitic fraction, opening the way for an economic use of the products of separation.

\section{CHEMICAL CHARACTERIZATION OF THE LITHOMARGIC CLAY}

Representative samples from the two sets of samples were prepared for elemental analysis by atomic absorption spectrophotometer, first by pulverizing each sample in a laboratory mill. Thereafter, about $0.1 \mathrm{~g}$ portions of these were weighed into Teflon beakers of a laboratory autoclave unit. A quantity of hydrofluoric acid (HF) was added to each beaker and the pulp digested at $160^{\circ} \mathrm{C}$ for one hour. After cooling, a solution of boric acid was added and the entire content transferred quantitatively into 100-ml measuring flasks and made up to the mark with distilled water. These were anlaysed on a Perkin Elmer M1000-B atomic absorption spectrophotometer for $\mathrm{Al}, \mathrm{Si}, \mathrm{Ti}, \mathrm{Fe}, \mathrm{Na}, \mathrm{K}$, and $\mathrm{Mg}$. The oxide compositions were then calculated and tabulated as presented in Tables 2 and 3.

Results of the analyses showed that the samples had varied composition. Samples A1, A2, A5, $\mathrm{BW} 3$ and $\mathrm{BW} 4$ had relatively low levels of impurity $\left(\mathrm{Fe}_{2} \mathrm{O}_{3}+\mathrm{TiO}_{2}+\mathrm{K}_{2} \mathrm{O}+\mathrm{Na}_{2} \mathrm{O}\right)$. The other samples may probably require beneficiation to reduce the iron content depending on the use to which the clay will be put.

\section{MINERALOGY}

For the purpose of mineralogical characterization of the sampled material, a representative group from the north-western section was subjected to routine Differential Thermal Analysis (DTA).

Table 2: The oxide composition (wt \%) of the first batch of samples from the north-western section of the mine

\begin{tabular}{lccccc}
\hline $\begin{array}{c}\text { Component } \\
\text { Colour/Oxide }\end{array}$ & $\begin{array}{c}\text { Sample A1 } \\
\text { Pale yellowish } \\
\text { white }\end{array}$ & $\begin{array}{c}\text { Sample A2 } \\
\text { Pale yellow }\end{array}$ & $\begin{array}{c}\text { Sample A3 } \\
\text { Pale reddish } \\
\text { brown }\end{array}$ & $\begin{array}{c}\text { Sample A4 } \\
\text { Reddish } \\
\text { brown }\end{array}$ & $\begin{array}{c}\text { Sample A5 } \\
\text { Whitish and } \\
\text { greasy }\end{array}$ \\
\hline $\mathrm{SiO}_{2}$ & 27.00 & 31.90 & 35.90 & 33.90 & 37.60 \\
$\mathrm{Al}_{2} \mathrm{O}_{3}$ & 45.90 & 45.90 & 40.90 & 43.70 & 44.02 \\
$\mathrm{Fe}_{2} \mathrm{O}_{3}$ & 1.22 & 1.33 & 9.92 & 9.92 & 0.37 \\
$\mathrm{TiO}_{2}$ & 2.20 & 1.63 & 1.68 & 1.96 & 1.24 \\
$\mathrm{~K}_{2} \mathrm{O}$ & 0.41 & 0.53 & 0.45 & 1.78 & 0.13 \\
$\mathrm{Na} 2 \mathrm{O}$ & 0.12 & 0.08 & 0.07 & 0.19 & 0.05 \\
$\mathrm{MgO}$ & 0.03 & 0.03 & 0.02 & 0.05 & 0.02 \\
Impurity level & 3.95 & 3.57 & 12.12 & 13.85 & 1.79 \\
\hline
\end{tabular}


Table 3: The oxide composition (wt \%) of the second batch of samples from the southwestern section of the mine

\begin{tabular}{lcccc}
\hline $\begin{array}{c}\text { Component } \\
\text { Colour/Oxide }\end{array}$ & $\begin{array}{c}\text { Sample BW1 } \\
\text { Reddish brown }\end{array}$ & $\begin{array}{c}\text { Sample BW2 } \\
\text { Light brown }\end{array}$ & $\begin{array}{c}\text { Sample BW3 } \\
\text { Pale pinkish white }\end{array}$ & $\begin{array}{c}\text { Sample BW4 } \\
\text { Pale yellowish white }\end{array}$ \\
\hline $\mathrm{SiO}_{2}$ & 32.10 & 33.10 & 36.40 & 38.30 \\
$\mathrm{Al}_{2} \mathrm{O}_{3}$ & 31.10 & 35.20 & 38.50 & 35.10 \\
$\mathrm{Fe}_{2} \mathrm{O}_{3}$ & 18.10 & 4.70 & 0.70 & 1.10 \\
$\mathrm{TiO}_{2}$ & 1.00 & 1.30 & 1.40 & 1.60 \\
$\mathrm{~K}_{2} \mathrm{O}$ & 0.80 & 0.40 & 0.40 & 0.60 \\
$\mathrm{Na}_{2} \mathrm{O}$ & 0.01 & 0.02 & 0.01 & 0.01 \\
Impurity level & 19.91 & 6.42 & 2.51 & 3.31 \\
Loss on Ignition & 15.80 & 17.80 & 18.70 & 17.30 \\
\hline
\end{tabular}

X-ray Diffraction Technique (XRD) was also employed in the determination of the mineral phases present in the lithomargic clay samples obtained from the south-western section of the mine.

\section{Differential Thermal Analysis (DTA)}

Four samples were analysed using a differential thermoanalyzer (DTA) at the Council for Scientific and Industrial Research (CSIR) laboratories in Accra, Ghana to determine the behaviour of the samples as well as phase changes during heat treatment. The curves obtained showed two clear endothermic peaks for each sample tested, as summarized in Table 4. The position of peaks on a derivatogram is greatly affected by the rate of heating and the crystallinity of the mineral.

Table 4: The positions of the endothermic peaks of samples from the north-western section of the mine

\begin{tabular}{lcc}
\hline Sample Identity & $\mathbf{1}^{\text {st }}$ Peak, ${ }^{\circ} \mathbf{C}$ & $\mathbf{2}^{\text {nd }}$ Peak, ${ }^{\circ} \mathbf{C}$ \\
\hline Sample A1 & 312.5 & 585.5 \\
Sample A2 & 335.5 & 600.0 \\
Sample A3 & 324.5 & 612.5 \\
Sample A5 & 306.8 & 604.8 \\
\hline
\end{tabular}

According to Tamás (1970), kaolinite, a clay mineral, exhibits two endothermic peaks around $100^{\circ} \mathrm{C}$ and $600^{\circ} \mathrm{C}$ whilst goethite, an iron mineral has an endothermic peak between $300-400^{\circ} \mathrm{C}$. At the same time, gibbsite has an endothermic peak between $320-350^{\circ} \mathrm{C}$ whilst boehmite has an endothermic peak between 530 $-550^{\circ} \mathrm{C}$. It is therefore possible for the endothermic peaks between 300 and $340^{\circ} \mathrm{C}$ to correspond to the combined de-hydroxylation of goethite and gibbsite. Chemical analysis of samples A1, A2 and A5 showed very little iron content, an indication that the peaks between $300-340^{\circ} \mathrm{C}$ belong to gibbsite. The second peak for each sample clearly reflects the dehydroxylation of kaolinite.

\section{X-ray Diffraction (XRD) Analysis}

An X-ray diffraction examination was carried out on all four samples, namely, BW1, BW2, BW3 and BW4 by means of Siemen D5000 powder diffraction unit. The diffraction patterns of the four samples were similar, showing kaolinite and gibbsite as the main minerals present. Figures 2 and 3 show the diffraction patterns obtained for BW1 and BW4 respectively.

The minor minerals with varying relative amounts in all the samples include rutile and biotite/muscovite. Goethite was present in the brownish samples (BW1 and BW2). The ratio of these minor minerals varied from one sample to the other. Quartz was absent from all the samples examined.

Sample BW4 was wet sieved into the following size fractions: less than $90 \mu \mathrm{m}$, between 90 to less than $250 \mu \mathrm{m}$ and 250 to $500 \mu \mathrm{m}$. Their combined diffraction patterns are presented in 


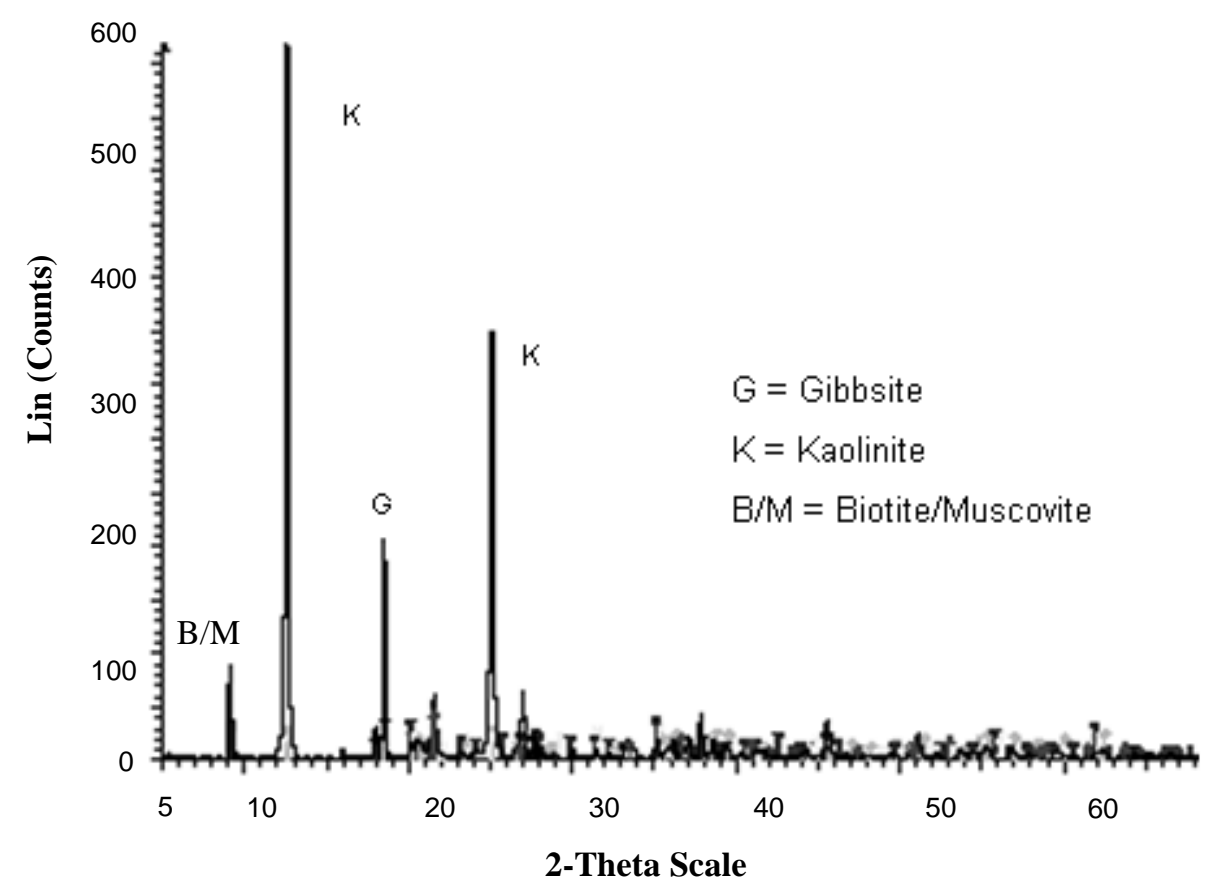

Fig. 2: X-ray diffraction pattern of lithomargic clay sample BW1

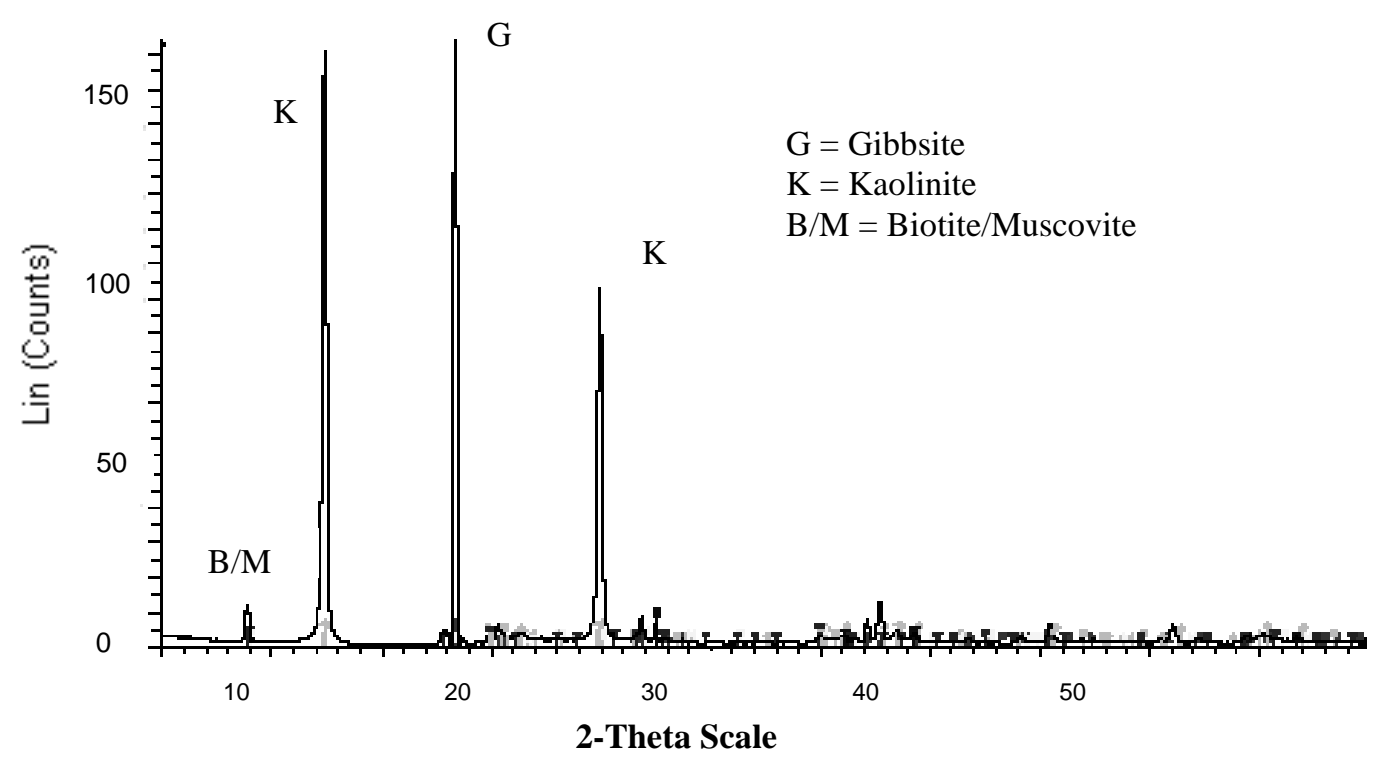

Fig. 3: X-ray diffraction pattern of lithomargic clay sample BW4 
Figures 4 and 5. Figure 4 shows the relative peak heights of kaolinite phase at $d=7.160$ for the raw and various size fractions, whilst those

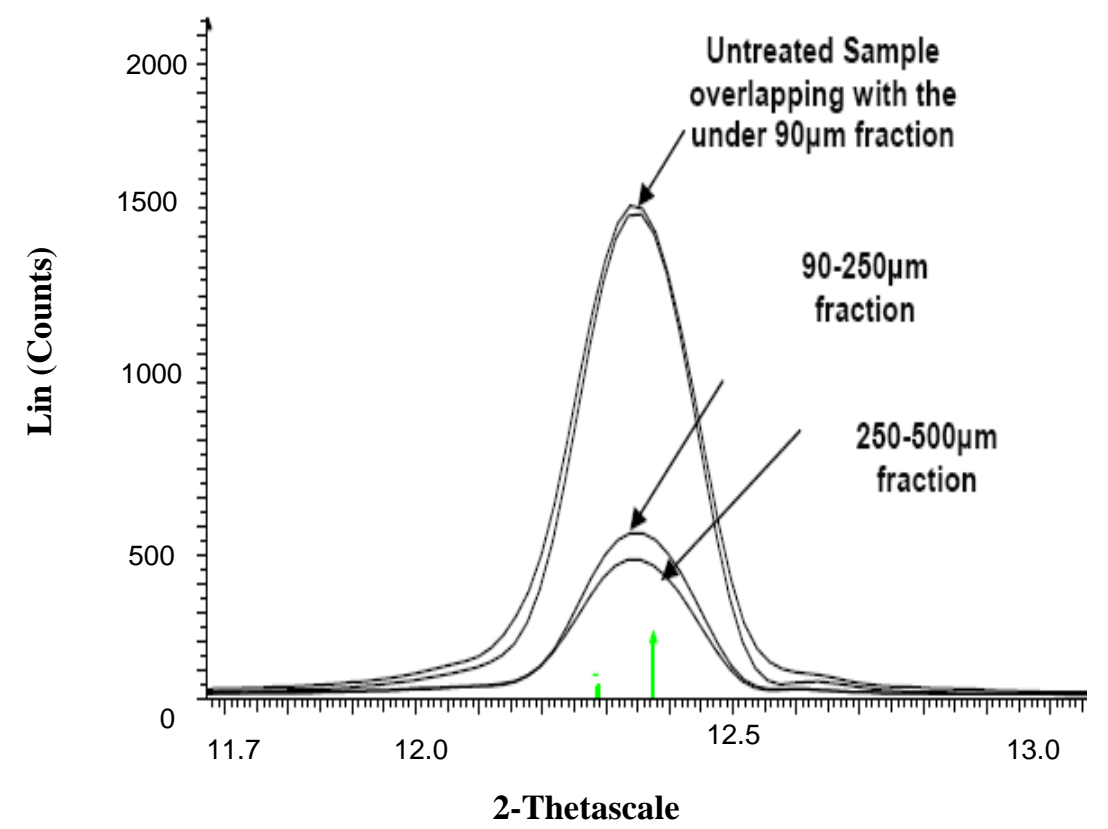

Fig. 4: The relative peak heights of kaolinite phase at $d=7.160$ for the raw sample and various size fractions

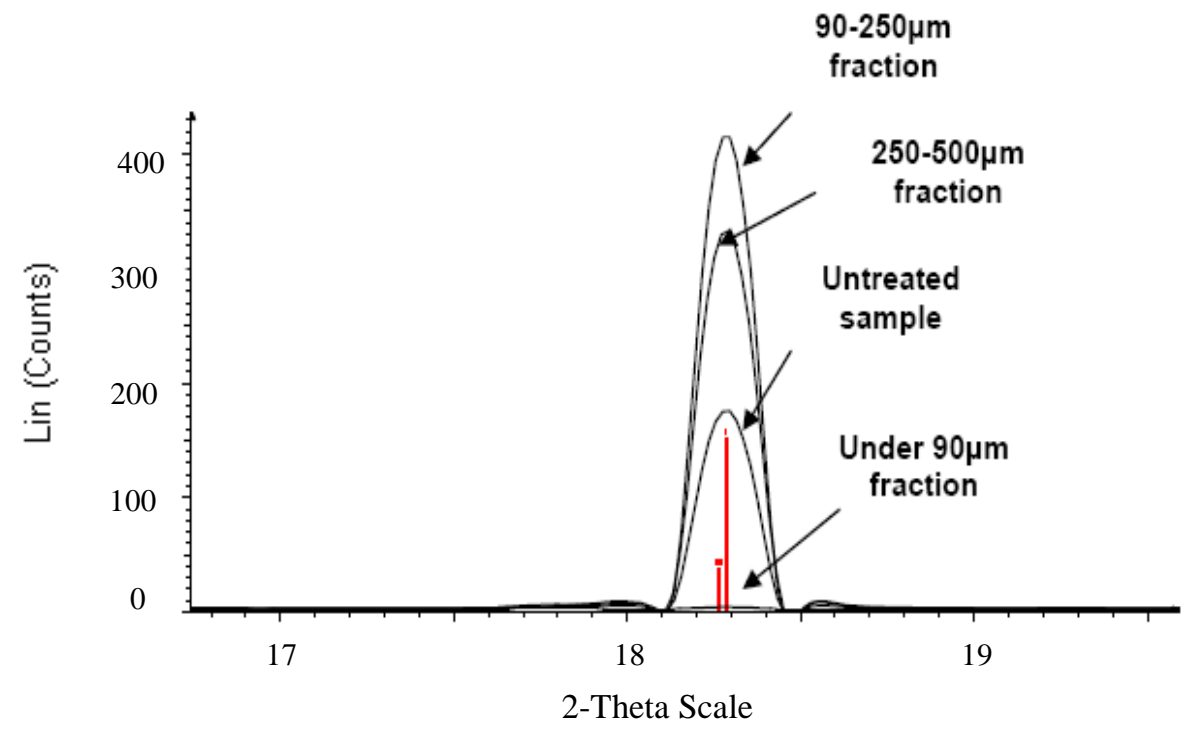

Fig. 5: The relative peak heights of the gibbsite phase at $d=4.84$ for the raw sample and various size fractions

102 Journal of Science and Technology, Vol. 29, No. 2, Aug., 2009 
ite and only a small amount of gibbsite, whilst that retained above $90-\mu \mathrm{m}$ sieve contained mainly gibbsite and a relatively small amount of kaolinite. Rutile seemed to be present in about the same amount in all fractions. These results may be of practical importance in the processing of the clay to obtain various products.

\section{INDUSTRIAL APPLICATION OF THE LITHOMARGIC CLAY}

Certain deductions could be made from the results of the chemical and mineralogical characterization of the lithomargic clay from the Awaso bauxite mine. The clay may be classified into two grades, namely, the low-iron (containing less than $1.5 \mathrm{wt} \%$ as $\mathrm{Fe}_{2} \mathrm{O}_{3}$ ) and the high-iron (containing more than $1.5 \mathrm{wt} \%$ as $\mathrm{Fe}_{2} \mathrm{O}_{3}$ ) grade. The so-called low-iron grade clay is suitable as raw material for the production of good quality alumino-silicate refractories and aluminium sulphate (alum). This grade of clay could also be washed and classified into kaolinitic clay and relatively pure gibbsite fractions, which could find further industrial applications. Some diagnostic evaluative investigations have been carried out in these directions with some good results as outlined below.

\section{Alumino-silicate refractory production}

Even though new types of refractory materials have been developed, traditional fireclay products still hold the largest share in the production of refractory. These are relatively cheap and are used in furnaces in the ceramics and metallurgical industries.

For fireclay refractory manufacture it is required that the raw material must have an $\mathrm{Al}_{2} \mathrm{O}_{3}$ content of between $15-46 \%$, the upper limit corresponding to the $\mathrm{Al}_{2} \mathrm{O}_{3}$ content of pure dehydrated kaolinite (Hlaváč, 1983). In addition, the total impurity content (including alkali, alkali-earth, metal oxide and iron oxide) should not be more than $2 \%$. These conditions can be satisfied by the white clays, which assayed $<2$ wt $\%\left(\mathrm{~K}_{2} \mathrm{O}+\mathrm{Na}_{2} \mathrm{O}+\mathrm{Fe}_{2} \mathrm{O}_{3}\right)$ and 35 wt \%-39 wt $\% \mathrm{Al}_{2} \mathrm{O}_{3}$ (Tables 2 and 3 ). The titania content is generally low (less than $2 \%$ ) but can be disastrous if the alumina content is low.
Investigations have also shown (Gawu and Momade, 1998) that it is possible to reduce the iron oxide content of the samples with higher iron oxide (up to $5 \% \mathrm{Fe}_{2} \mathrm{O}_{3}$ ) content by first magnetizing roasting with charcoal followed by magnetic separation. This method could reduce the $\mathrm{Fe}_{2} \mathrm{O}_{3}$ content from about $4.7 \%$ to about $2.4 \%$. However, the non-magnetic portion could still not be used as a raw material for fireclay production.

For the tests, two size fractions $(<90 \mu \mathrm{m}$ and $>$ $90 \mu \mathrm{m}$ ) of sample BW4 were balled up and heated in a muffle furnace at various temperatures up to $1250^{\circ} \mathrm{C}$ (the limit of temperature attainable in our furnaces at the laboratories) for various lengths of time. In industrial practice a temperature of at least $1400^{\circ} \mathrm{C}$ is required to produce the grog from which refractory bricks are prepared. X-ray powder diffraction analysis was carried out on the heat treated samples. The x-ray diffraction pattern of the < $90 \mu \mathrm{m}$ fraction after treatment at $1250^{\circ} \mathrm{C}$ is presented in Figure 6. The predominant phases in the heat-treated material are mullite and cristobalite. The presence of these phases indicates a successful transformation of the raw material into a refractory material. In the case of the > $90 \mu \mathrm{m}$ fraction (Figure 7), corundum phase was present in addition to the mullite phase in the heat-treated material.

The option to separate kaolinitic fraction from the gibbsitic fraction in the lithomargic clay has offered the chance to blend raw material to obtain a specific product. These findings are important for the Ghanaian metallurgical industry where various types of alumino-silicate refractories are used in lining metallurgical furnaces. The growth of foundry activities in Ghana and in the West African sub-region will require a higher demand for refractory linings.

The industrial application of the so-called highiron grade would be very much limited because of the relatively high iron content. However, it could be calcined and used as pigment in paint manufacture or it could be beneficiated to remove the iron content by magnetic separation after reductive roasting. It could also be washed to remove the gibbsite content, which could be 


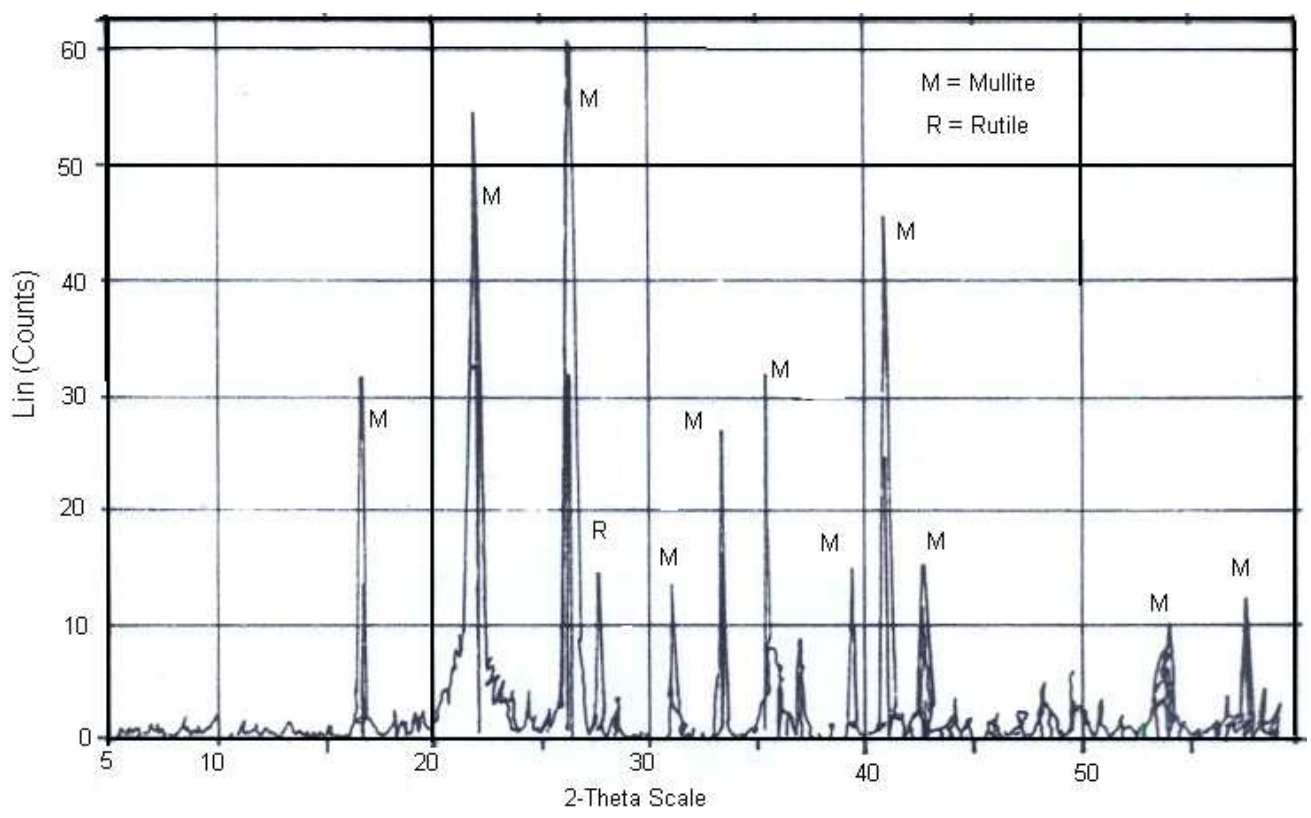

Fig. 6: $X$-ray diffractogram of the less than $90 \mu \mathrm{m}$ fraction of the white lithomargic clay treated at $1250^{\circ} \mathrm{C}$ for $3 \mathrm{~h}$

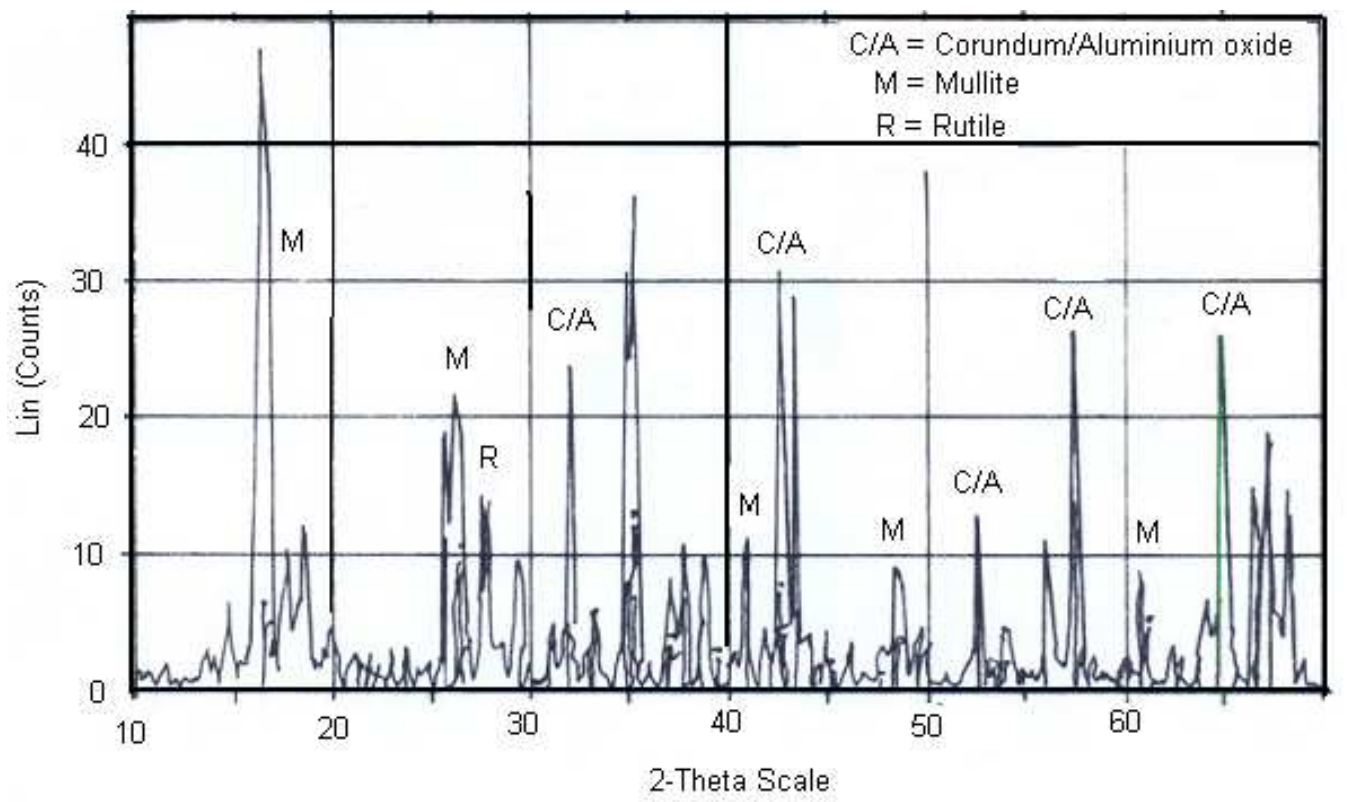

Fig. 7: X-ray diffractogram of the more than $90 \mu \mathrm{m}$ fraction of the white lithomargic clay treated at $1250^{\circ} \mathrm{C}$ for $3 \mathrm{~h}$.

104 Journal of Science and Technology, Vol. 29, No. 2, Aug., 2009 
used as a supplementary material in aluminosilicate refractory material preparation. However, cost-benefit analysis is required to be done to ascertain its feasibility.

\section{Aluminium sulphate (Alum) production}

Aluminium sulphate has a number of applications very vital to human health and other activities of man. These include, among others, its use in the purification of water, paper production, textile dyeing industry, pharmaceutical preparations, leather tanning, clarifying agent for fats and oils used for soap, grease production and the deodorisation of mineral oils. However, the most important use is in the purification of water for domestic and industrial use.

Alum is available in an anhydrous form with a chemical formula $\mathrm{Al}_{2}\left(\mathrm{SO}_{4}\right)_{3}$ whilst the hydrated form has the formula $\mathrm{Al}_{2}\left(\mathrm{SO}_{4}\right)_{3} \cdot 18 \mathrm{H}_{2} \mathrm{O}$. Commercially, there are two grades - the technical (or commercial grade) and the iron-free grade. The iron-free grade contains only $0.01 \% \mathrm{Fe}_{2} \mathrm{O}_{3}$ as compared to about $0.04 \% \mathrm{Fe}_{2} \mathrm{O}_{3}$ in commercial grade alum. The iron-free grade is used in the manufacture of special high quality papers, dyes, and pharmaceuticals.
Aluminium sulphate may be produced by any of the following methods:

i) Action of $\mathrm{H}_{2} \mathrm{SO}_{4}$ on $\mathrm{Al}(\mathrm{OH})_{3}$

ii) Action of $\mathrm{H}_{2} \mathrm{SO}_{4}$ on aluminium silicates (clays)

iii) Action of $\mathrm{H}_{2} \mathrm{SO}_{4}$ on bauxite.

The lithomargic clay is therefore a potential candidate for the production of aluminium sulphate. The apparent advantage in using the lithomargic clay lies in the fact that it contains not only kaolinite but also gibbsite and can be selected to minimize iron oxide content.

Tests conducted on the lithomargic clay (Gawu and Momade, 1998) indicated that best results were obtained by first calcining the clay at about $700^{\circ} \mathrm{C}$ to break the kaolinite structure, followed by leaching with sulphuric acid. Crystals that compared very well in performance with imported aluminium sulphate were produced under laboratory conditions from the leach solution. Figure 8 shows the comparison between the diffraction patterns of the product sulphate and imported sulphate. Table 5 presents the results of jar tests conducted on water from Owabi water reservoir in Kumasi, Ghana. These results show a good comparison between

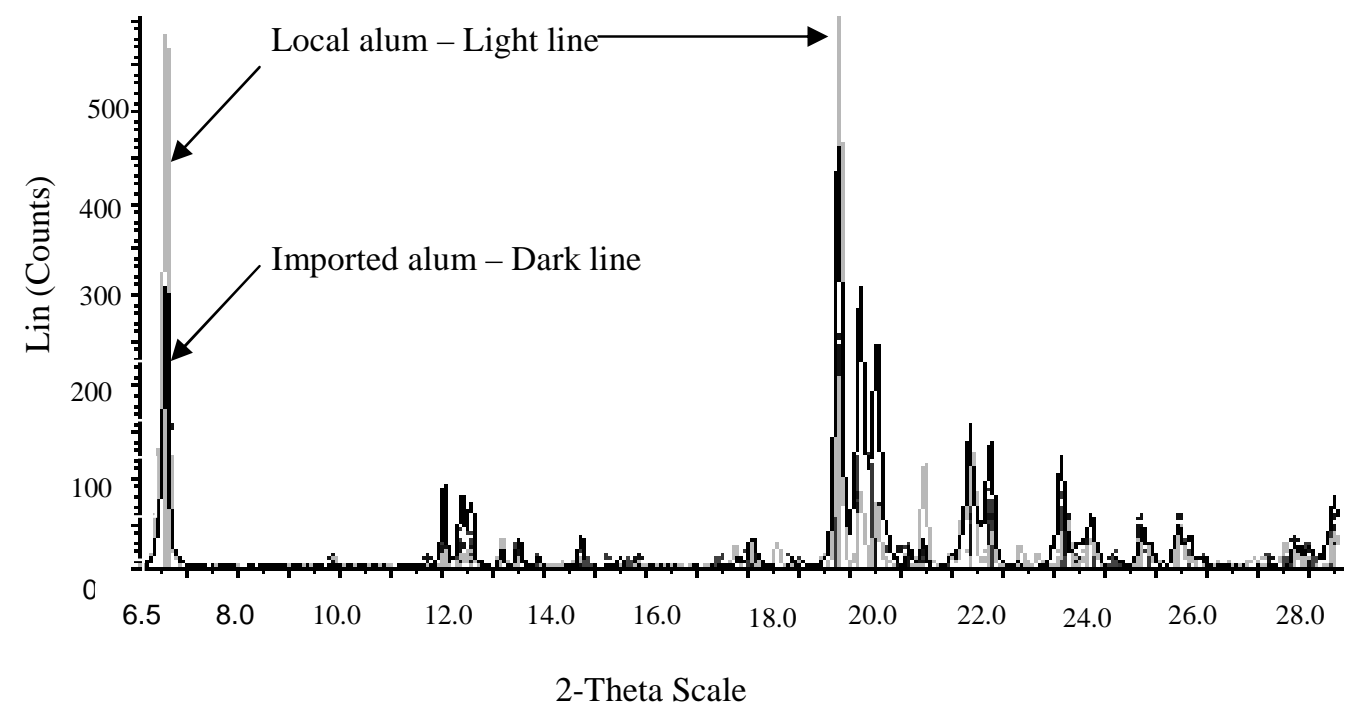

Fig. 8: A comparison of the diffraction patterns of the imported and locally produced alum 
Table 5: Results of jar tests conducted with product crystalline alum (from the lithomargic clay) and imported alum with water from the Owabi reservoir

\begin{tabular}{ccccccccc}
\hline $\begin{array}{c}\text { Dosage } \\
(\mathbf{p p m})\end{array}$ & \multicolumn{2}{c}{$\mathbf{p H}$} & \multicolumn{2}{c}{$\begin{array}{c}\text { Colour } \\
\text { (Haizen) }\end{array}$} & \multicolumn{2}{c}{$\begin{array}{c}\text { Turbidity } \\
\text { (NTU) }\end{array}$} & \multicolumn{2}{c}{$\begin{array}{c}\text { TDS } \\
\text { (mg) }\end{array}$} \\
& Local & Import & Local & Import & Local & Import & Local & Import \\
\hline 0.0 & 7.32 & 7.32 & 275.0 & 275.0 & 29.1 & 29.1 & 136 & 136 \\
60.0 & 7.04 & 6.88 & 200.0 & 150.0 & 15.1 & 17.3 & 142 & 141 \\
70.0 & 6.88 & 6.88 & 150.0 & 125.0 & 13.1 & 13.7 & 144 & 143 \\
80.0 & 6.77 & 6.60 & 75.0 & 75.0 & 0.83 & 0.64 & 161 & 154 \\
\hline
\end{tabular}

the performance of the locally produced and imported aluminium sulphate.

\section{CONCLUSION}

The characteristics of the lithomargic clays from the Awaso bauxite deposit were investigated through physical, elemental and mineralogical analysis. An evaluation of these materials has shown that they can be applied to the production of aluminium sulphate and refractory material. These clay types which were hitherto regarded as waste during mining could now be exploited as a resource more profitably. The raw clay will however have to be beneficiated in order to optimize grade and recovery.

\section{ACKNOWLEDGEMENT}

The project on the characterization of the lithomargic clays was funded by the Ghana Chamber of Mines. The authors are grateful to the Chamber for the support. We also thank the management of Ghana Bauxite Company for permission to collect samples and carry out this investigation on their samples.

\section{REFERENCES}

Acquah, F., Mensah, B. and Obeng, Y. (1999). Production of alum from Awaso bauxite. The Ghana Engineer. Reprinted with GhIE permission by African Technology Forum [online] http://home.att.net/ africantech/ GhIE/Awaso1.htm [accessed 12 August 2009].

Appiagyei, A.K. (1993). Development of alumino-silicate refractories from local raw materials. MPhil. Thesis, Kwame Nkrumah University of Science and Technology, Kumasi pp.57-71.
Gawu, S.K.Y. (1993). Ore petrology and geochemistry of the Ichiniso bauxite deposit, Awaso, Ghana. MPhil. Thesis, Kwame Nkrumah University of Science and Technology, Kumasi. 80pp.

Gawu, S.K.Y. (1997). Geochemical trends of the Ichiniso bauxite deposit, Awaso, Ghana. Ghana Mining Journal, vol. 3, (1 \& 2). pp. $10-17$.

Gawu, S.K.Y. and Momade, F.W.Y. (1998). Progress Report on the Characterisation of the Awaso Lithomargic clay for the Ghana Chamber of Mines, Report Two. 38p.

Hlavăc, J. (1983). The Technology of Glass and Ceramics. An Introduction. Elsevier Scientific Publishing Company, Amsterdam. pp 370-373.

Hurlburt, Jr., C.S. and Sharp, W.E. (1998). Dana's Minerals and How to Study Them., John Wiley \& Sons, New York, pp. 189190.

Kesse, G.O. (1985). The Mineral and Rock Resources of Ghana. A.A. Balkema, Rotterdam, Netherlands, pp. 95-156.

Shankar, A.U.R and Suresha, S. N (2006). Strength behaviour of geogrid reinforced shedi soil subgrade and aggregate system. Road materials and pavement design, vol. 7 (3). pp. 313-330.

Tamás Ferenc (1970). Szilikátipari Laboratórium Vizsgálatok Muszaki Könyvkiadó, Budapest. pp. 282-288. 